UDC: $351: 004$

JEL: L 86

\title{
POSSIBILITIES OF APPLICATION FINTECH IN IMPROVING THE ORGANIZATION ADMINISTRATIVE SERVICES PROVISION BY LOCAL AUTHORITIES
}

\author{
МОЖЛИВОСТІ ЗАСТОСУВАННЯ FINTЕСН \\ В УДОСКОНАЛЕННІ ОРГАНІЗАЦІЇ НАДАННЯ АДМІНІСТРАТИВНИХ \\ ПОСЛУГ ОРГАНАМИ МІСЦЕВОГО САМОВРЯДУВАННЯ
}

\author{
Sergey A. Sambros \\ Odessa National Polytechnic University, Odessa, Ukraine \\ ORCID: 0000-0002-9861-9359 \\ Email: strannyjsergej@gmail.com
}

Oleksandr S. Balan, Doctor of Economics, Professor Odessa National Polytechnic University, Odessa, Ukraine ORCID: 0000-0001-6711-5687

Email: shurabalan@ukr.net

Vira V. Lebedeva, Doctor of Science (Economics), Professor Odessa National Polytechnic University, Odessa, Ukraine ORCID: 0000-0002-3609-3697

Email:veralebedeva@ukr.net

Received 16.01.2020

Самброс С.А., Балан О.С., Лебедєва В.В. Можливості застосування Fintech в удосконаленні організації надання адміністративних послуг органами місиевого самоврядування. Оглядова стаття.

Стаття присвячена висвітленню використання інформаційних систем у сфері публічного управління, а саме можливості застосування FinTech технологій в процесі надання адміністративних послуг органами місцевого самоврядування. Проаналізовано зарубіжний досвід надання адміністративних послуг, а також перспективи та усі переваги їх запровадження в Україні. Визначено основні переваги та недоліки цих технологій та технік. Зроблено висновки та представлені пропозиції щодо вдосконалення та впровадження нових та старих адміністративних послуг, а також використання інакших методів передачі інформації.

Ключові слова: інформачійні системи, публічне управління, адміністративні послуги, електронне урядування, інновації, база даних.

Sambros S.A., Balan O.S., Lebedeva V.V. Possibilities of application Fintech in improving the organization administrative services provision by local authorities. Review article.

The article is devoted to the coverage of the use of information systems in the field of public administration, namely the possibility of using FinTech technologies in the process of providing administrative services by local governments. The foreign experience of providing administrative services is analyzed, as well as prospects and all advantages of their introduction in Ukraine. The main advantages and disadvantages of these technologies and techniques are identified. Sufficient conclusions were drawn and suggestions were made regarding the improvement and implementation of new and old administrative services, as well as using other methods of information transmission.

Keywords: information systems, public administration, administrative services, e-government, innovations, database.

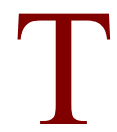

oday, we are already living in a time of information technologies rapid development, it is impossible to imagine efficient and quality work in any industry without using software and other tools of electronic document circulation. New tools are emerging every day to optimize all areas of human activity.

Specialists in the field of information and telecommunication technologies, lawyers, politicians, civil servants, as well as citizens of our country, widely discuss the introducting new information systems for circulation, broadcasting and receiving information, serving consumers or partners, or even other structures or countries of the world, for providing administrative services in all industries.

The issue of implementing information systems in the area of administrative services provision in Ukraine is very urgent, because there is a problem of trust in public authorities and a corruption problem in the country. In addition, information systems allow to solve a number of problems that are present in the work of governmental bodies nowadays, in particular, the fight against bureaucracy, corruption and improving the administrative services level.

Therefore, the aim of this article is to determine the prospects of introducing information systems in Ukraine in the area of administrative services provision, outline the advantages and disadvantages of these information systems and administrative 
services systems, as well as to analyze the international experience of providing administrative services. Therefore, the issue of administrative services provision, mobility and delivery in public administration and local authorities is also burning.

The analysis of recent researches and publications

To date, the administrative services provision is of great importance to secure the vital arteries and interests of any state. Creating a developed and protected environment is a prerequisite for the society and the state development, and, above all, the trust in civil servants and govermental and municipal authorities, which must be based on the latest automated technical means and qualified specialists.

Recently, there have been some qualitative changes in management processes at all levels in Ukraine, which were caused by the intensive introduction of new information technologies, as well as the work monitoring of all specialists of govermental and public administration at all levels.

The rapid informatization improvement, its penetration into all spheres of vital interests caused, besides the undeniable advantages, the number of strategic problems has been emerged. The risk of unauthorized interference with the operation of computer, information and telecommunications and other systems is increasing.

The aim of the article is to identify the prospects for the using the information technologies in Ukraine in the field of public administration and improve the administrative services provision, namely the administrative services provision by local authorities, highlight the advantages and disadvantages of these transformations, as well as to analyze the already used administrative services.

\section{The main part}

The practice of providing administrative services in Ukraine proves that there are many problems in the process of obtaining administrative services by citizens. This fact is confirmed by the data of many specific studies on the administrative services quality. Thus, in the assessment of administrative services quality, the opinions of Ukraine's population were divided as follows: $33 \%$ gave a satisfactory rating, good $-12 \%$ and $32 \%$ - bad. In addition, $11 \%$ of the population bribed administrative services, saying that it was "easier and more simply to solve their problems" [1]. These results indicate a rather poor quality of administrative services provision and dissatisfaction with those providing the latter to the majority of Ukraine's population. According to the results of "Doing business rating" in 2014, the main problems of providing administrative services in the permitting and registration sphere were the high losses of time and the cost of obtaining the corresponding service (Table 1).

Table 1. Ease indexes of obtaining administrative services in Ukraine compared to other groups of countries

\begin{tabular}{|c|c|c|c|}
\hline Indicator & Ukraine & Europe and Central Asia & OECD \\
\hline \multicolumn{4}{|l|}{ Obtaining a building permiionss } \\
\hline Procedures (quantity) & 10 & 18 & 13 \\
\hline Period (days) & 73 & 192.2 & 147.1 \\
\hline Cost ( $\%$ of average per capita income) & 607.1 & 327.1 & 84.1 \\
\hline \multicolumn{4}{|l|}{ Property registration } \\
\hline Procedures (quantity) & 8 & 6 & 5 \\
\hline Period (days) & 45 & 26.5 & 24.1 \\
\hline Cost (\% of average per capita income) & 1.9 & 2.8 & 4.4 \\
\hline \multicolumn{4}{|l|}{ Connection to the power supply system } \\
\hline Procedures (quantity) & 10 & 6 & 5 \\
\hline Period (days) & 277 & 146 & 89 \\
\hline Cost ( $\%$ of average per capita income) & 178 & 486.6 & 79.1 \\
\hline
\end{tabular}

Source: compiled by autor on materials [3].

It is noted that among these most inadmissible elements in the administrative services provision: long queues, lack of clear explanations about all the circumstances of the case and the necessary documents, red tape with processing the case were most often mentioned. As we can see in the foreground among the problems in obtaining administrative services was the complexity and the process opacity of obtaining administrative services and a long waiting time for the result. Therefore, the creation of convenient, understandable and accessible conditions for citizens to receive administrative services is one of the main tasks to be addressed by public and local authorities. This task implementation is extremely important for Ukraine at the present 
stage of development, where the system of providing administrative services is opaque, irrational and slow.

However, it should be noted that in 2014, Ukraine already took the first positive steps in reforming the administrative service delivery system, in particular, accepting Georgia's proposal to modernize the registration system in Ukraine. At the same time, according to the former Solicitor-General of Georgia Georgy Vashadze, "... now one of the most important tasks for Ukraine is to create unified centres of administrative services. Our concept provides for the possibility of round-the-clock access of citizens to the necessary services and the construction of the most comfortable for the population buildings of administrative centres with well-thought-out internal logistics, which will prevent the queues formation" [1]. Certainly, the chosen vector of change is appropriate and promising, but the centres network creation, in our opinion, is only one of the conditions for the reorganization of the administrative services system. Despite significant developments in the field of administrative services theory and practice, the process of organizing their provision remains the subject of special research interest in modern scientific discourse. The Law of Ukraine "On Administrative Services" provides an official definition of an administrative service as a result of the authoritative powers exercise by the administrative services subject at the request of a natural or legal person aimed at acquiring, changing or terminating the rights and / or obligations of such a person [1].

We can see that there are no particular problems with the administrative service definition, whereas with a comprehensive and unique list of administrative services provided in Ukraine, the situation looks different. To date, no regulatory legal act has approved an exhaustive list of administrative services, and a situation arises when the entities providing administrative services independently decide what administrative services they provide.

The uncertainty of an exhaustive list of administrative services to be provided to the public by the subjects of administrative services results in inconsistencies between the latter and under-coverage of the needs for the population's administrative services. Moreover, such a regulation level of a citizen's life indicates that in Ukraine it is extremely difficult to acquire, change or terminate any rights and obligations. In fact, it turns out that this administrative service is divided into $5-6$ small services, i.e. the cost of time and money for one administrative service is disproportionately large, and corruption risks are quite significant - at each stage of receiving administrative services a citizen faces officials and new requirements for the necessary documents to obtain the service. For a more detailed problems analysis, it is necessary to consider the current technology of obtaining administrative services. To do this, one can divide the whole process of obtaining the service into three stages. At each of them a citizen is faced with problematic aspects [2]. At the first stage of "Documents collection and preparation" the problem essence is as follows: 1. Lack of a standard application form to be submitted by a citizen, and free access to it. It is stated that the application to the executive body is submitted in any or typical form, if the latter is developed by the authority. However, the standard form is not developed in all authorities and is not posted on the sites of the administrative service centers [2].

Table 2. The number of administrative services according to various sources

\begin{tabular}{|l|c|}
\hline $\begin{array}{c}\text { The source that provides data on number of administrative } \\
\text { services in Ukraine }\end{array}$ & The number of administrative services \\
\hline Ministry for development of economy and trade in Ukraine & 1130 \\
\hline $\begin{array}{l}\text { Law of Ukraine "On the list of administrative services and } \\
\text { fees (administrative fee) for their provision" }\end{array}$ & 129 \\
\hline Register of administrative services & 1203 \\
\hline
\end{tabular}

Source: compiled by autor on materials [1, 3, 4]

Thus, we see that an applicant may or may not know what the application, questionnaire or formsheet should look like and what it should contain, so there is a problem of the application incorrect writing and repeated visits to the executive body. Since a rule has been laid down at the legislative level which determines the basis for the technical documentation development, without which it is impossible to obtain this administrative service, the decisions of the executive authority, on the basis of the survey results, in practice, this documentation developer will not produce it without this solution. Therefore, the problem is that, according to the legislation, citizens and developer are entitled to conclude a contract for the production of technical documentation in case of failure to produce a solution within a certain time period as a citizen, but in practice developers «reinsure» and refuse to enter into a contract without a decision due to the lack of a well-established practice of producing documentation without a decision and because it is difficult today to prove that the application was filed by a citizen and has not been answered within the agreed deadline [2].

According to the survey results, the developers do not always submit this technical documentation to the state cadastral registrar (as provided by the 
legislation), they usually give it to a citizen and he/she already works independently with it further. During the inspection of the technical documentation by the state cadastral registrar, comments are made to it, errors are found, and grounds for refusal to provide the public service. Therefore, it is necessary for the developer to work up to the final result with the technical documentation. In Ukraine, there is a transition to electronic document management, so why one should submit a paper version of the technical documentation, which is currently required by current legislation. In addition, in the case of discrepancies between the paper and the electronic version, preference is given to the paper version, which is contrary to the order of electronic document management organization. According to the official website of the State Agency of Land Resources of Ukraine (hereinafter referred to as the State Land Agency), in 2016 in Ukraine, the normative monetary valuation of all the settlement lands was completed $100 \%$, therefore the data on the regulatory and monetary assessment are contained in the database of the State Land Resources Agency of Ukraine. The question arises why a citizen should apply for a legislative and monetary valuation to the State Land Resources Agency of Ukraine, and then submit this extract again to the State Land Resources Agency of Ukraine. The state cadastral registrar can obtain the necessary data by checking the technical documentation of the normative monetary valuation. Not only at the first stage, but for each stage where documents are submitted, there is a problem regarding the requirement of legibility in the documents completion, and no criteria for legibility have been established. Therefore, it may be denied in documents acceptance because of their illegible completion. Thus, it is necessary to provide computer filling of documents, in particular, personally by officials [3].

At the second stage, which consists in all the collected documents submission to the state cadastral registrar, the situation is better, but at this stage a citizen may have the problem of refusing to accept the documents because of an inexhaustive list or incorrect presentation, some administrative service providers also post electronic queues for applications and documents, and waiting times in this queue may be indefinite. At the third stage, when a citizen has to get the result, the main problem is the grounds duplication for refusing to accept the application with documents and refusing to provide the service due to the grounds duplication for submitting documents and obtaining an extract. Therefore, in order to address these issues, a new mechanism was proposed for the provision of administrative services "Introduction into the state land cadastre information (changes to them) about land within the territory of administrative territory units", which should be carried out with the help of Administrative Service Centres in order to simplify the mechanisms and reduce the receipt time of administrative services in relevant institutions, in particular permit documents [3]. The first step of the proposed mechanism is consultation to clarify the list of documents to be submitted to the Administrative Service Centre, as can be seen on the official CNAP website. At the second stage, a citizen has to submit documents to a CNAP administrator. The third step of the proposed procedure reflects the mechanism of providing administrative services. And the fourth step is getting the citizen an extract and technical documentation by e-mail when implementing electronic document management.

Thus, during the study it has been found that today there are a large number of practical problems in the administrative services provision due to imperfect legislation in this area. Among the most acute problems one can distinguish the following: the lack of a single register of administrative services in Ukraine that citizens can receive from entities providing administrative services at the legislative level, so that each entity providing administrative services independently determines the services list it provides, which leads to some services unavailability for the general public; the lack of transparency and incomprehensibility of the mechanism for obtaining a citizen's administrative service the entities providing these services; lack of sufficient public awareness of administrative services receipt due to the lack of a single clear mechanism for providing each service; complex process in obtaining administrative services [4].

\section{Abstract}

The practice of providing administrative services in Ukraine proves that there are many problems in the process of obtaining administrative services by citizens. This fact is confirmed by the data of many specific studies on the administrative services quality. Thus, in the assessment of administrative services quality, the opinions of $\mathrm{f}$ Ukraine's population were divided as follows: $33 \%$ gave a satisfactory rating, good $-12 \%$ and $32 \%$ - bad. In addition, $11 \%$ of the population bribed administrative services, saying that it was "easier and more simply to solve their problems".

The Law of Ukraine "On Administrative Services" provides an official definition of administrative service as a result of the authoritative powers exercise by the administrative services subject at the request of a natural or legal person aimed at acquiring, changing or terminating the rights and / or obligations of such a person.

We can see that there are no particular problems with the administrative service definition, whereas with a comprehensive and unique list of administrative services provided in Ukraine, the situation looks different. To date, no regulatory legal act has approved an exhaustive list of administrative services, and a situation arises when the entities providing administrative services independently decide what administrative services they provide. 
The first step of the proposed mechanism is consultation to clarify the list of documents to be submitted to the Administrative Service Centre, as can be seen on the official CNAP website. At the second stage, a citizen has to submit documents to an CNAP administrator. The third step of the proposed procedure reflects the mechanism of providing administrative services. And the fourth step is getting the citizen an extract and technical documentation by e-mail when implementing electronic document management.

Thus, the study revealed that today there are many practical problems with the administrative services provision due to imperfect legislation in this area. Among the most pressing problems are the following: the lack of a single register of administrative services in Ukraine that citizens can receive from legal entities providing administrative services, so that each administrative entity independently determines the services list it provides, which leads to the unavailability of some services to the general public; the lack of transparency and incomprehensibility of the mechanism for obtaining the administrative service of a citizen from the subjects of these services provision; lack of sufficient public awareness of administrative services through the lack of a single clear mechanism for each service; complex process of obtaining administrative service.

\section{Список літератури:}

1. Земельний кодекс України: Закон України від 25 жовтня 2001 р. // Відомості Верховної Ради України. - 2020. - № 3. - Ст. 27.

2. Закон України «Про адміністративні послуги» [Електронний ресурс]. - Режим доступу: http://zakon2.rada.gov.ua/laws/show/5203-17.

3. Пєтков С.В.Проблема раціонального використання часу в управлінській діяльності як основа ефективного менеджменту в органах внутрішніх справ України / С. В. Пєтков // Право і Безпека. — 2017.— T. 4, №3. — С. 79-82.— — Режим доступу: http://nbuv.gov.ua/UJRN/Pib_2017_4_3_23.

4. Туленков М.В., Чувардинський О.Г., Шайгородський Ю.Ж.Сучасний менеджмент (теорії, концепції, моделі): навч. посіб.- К.: Український центр політичного менеджменту. - 376 с.

5. Davydova, I., Balan, O., Danyliuk, O., Horbashevska, M., Bakulina, N., Samarchenko, I. Improvement of algorithms and procedures of decision support in the field of personnel management (2019) International Journal of Recent Technology and Engineering, 8 (4), pp. 2128-2132.

\section{References:}

1. Land Code of Ukraine: Law of Ukraine of October 25, 2001 // Bulletin of the Verkhovna Rada of Ukraine. - 2020. - № 3. - Art. 27.

2. Law of Ukraine "On Administrative Services" [Electronic resource]. - Access mode: http://zakon2.rada.gov.ua/laws/show/5203-17.

3. Petkov S.V. The Problem of Rational Use of Time in administrative Activity as the Basis of Effective Management in Law Enforcement Agencies of Ukraine / S.V. Petkov // Law and Security. - 2017.Vol. 4, №3. - P. 79-82. - Access mode: http://nbuv.gov.ua/UJRN/Pib_2017_4_3_23.

4. Tulenkov M.V., Chuvardinsky O.G., Shaygorodsky Y.U . Modern Management (Theories, Concepts, Models): textbook. Toolkit. - K: Ukrainian Center for Political Management. - 376 p.

5. Davydova, I., Balan, O., Danyliuk, O., Horbashevska, M., Bakulina, N., Samarchenko, I. Improvement of algorithms and procedures of decision support in the field of personnel management (2019) International Journal of Recent Technology and Engineering, 8 (4), pp. 2128-2132.

\section{Посилання на статтю:}

Sambros S.A., Balan O.S., Lebedeva V.V. Possibilities of application Fintech in improving the organization administrative services provision by local authorities / S.A. Sambros, O.S. Balan, V.V .Lebedeva // Economics: time realities. Scientific journal. - 2020 - № 1 (47). - P. 48-52. - Retrieved from https://economics.opu.ua/files/archive/2020/No1/48.pdf.

DOI: 10.15276/ETR.01.2020.6. DOI: 10.5281/zenodo.3967436.

\section{Reference a Journal Article:}

Sambros S.A., Balan O.S., Lebedeva V.V. Possibilities of application Fintech in improving the organization administrative services provision by local authorities / S.A. Sambros, O.S. Balan, V.V .Lebedeva // Economics: time realities. Scientific journal. - 2020 - № 1 (47). - P. 48-52. - Retrieved from https://economics.opu.ua/files/archive/2020/No1/48.pdf.

DOI: 10.15276/ETR.01.2020.6. DOI: 10.5281/zenodo.3967436. 